\title{
THE INFLUENCE OF FEDERAL PROCEDURAL REFORM
}

\author{
Charles E. Clark*
}

The recent reforms of procedure in the federal courts are unique not merely because of their advanced features, but also because they were professional reforms accomplished under professional auspices. This fact would not seem strange, did we not recall that in the past such changes have been forced upon the profession either by aroused lay feeling or by the determined sponsorship of some lone leader or by both. The century-long struggle in England, where the names of Bentham and Dickens figure so prominently, was largely lay-inspired. In American code reform-the foundation for modern civil procedure in England and America-the name of David Dudley Field towers in lonely eminence. His accomplishment, indeed, seems almost a tour de force, so quickly was it achieved; but then it had to run the gauntlet of court adjudication and unfortunate emasculation. In the classic statement of Chief Justice Winslow of Wisconsin, "The cold, not to say inhuman, treatment which the infant Code received from the New York judges is matter of history." Lawyers look to precedent and to the past; the habit of violent reaction against change is too firmly ingrained not to be recognized as a natural condition of procedural reform. ${ }^{2}$ But it is still possible for the profession to supply both effective leadership and expert execution of such projects. This was recognized by the leading figures of the American bar who conducted the long doubtful, but ultimately successful, campaign for court rule-making in the federal courts. And the reforms when secured now stand as successful models of practice systems developed by professional efforts and according to professional standards. This achievement,

*A.B. I91r, LL.B. 1913, A.M. 1923, Yale University. Judge of the United States Circuit Court of Appeals, Second Circuit, since 1939; member of and Reporter to the Advisory Committee on Rules of Civil Procedure of the Supreme Court of the United States since 1935; formerly Professor of Law and Dean (1929-1939) of the Yale University School of Law; President of the Association of American Law Schools, 1933. Author: Code Pleading (1928, 1947); Real Covenants (1929, 1947); Cases on Pleading and Procedure (1930, 1933, i934, i940); Probate Law and Practice of Connecticut (1915, supp. 1929) (with L. W. Cleaveland and Harrison Hewitt); Cases os PartNershtp (1932) (with W. O. Douglas); Law and Legal Institutions (with W. O. Douglas) in "Recent Social Trends" (1933); editor: A Study of the Business of the Federat Courts (2 vols. 1934); A Study of Law Administration in Connecticut (1937) (with Harry Shulman). Contributor to legal periodicals.

${ }^{1}$ McArthur v. Moffett, 143 Wis. $564,567,128$ N. W. 445,446 (19ro), adding: "They had been bred under the common-law rules of pleading and taught to regard that system as the perfection of logic, and they viewed with suspicion a system which was heralded as so simple that every man would be able to draw his own pleadings. They proceeded by construction to import into the Code rulcs and distinctions from the common-law system to such an extent that in a few years they had practically so changed it that it could hardly be recognized by its creators." See also ClaRk, Code Pleading 17-71, 83, 84 (2d ed. 1947); Sunderland, The English Struggle for Procedural Reform, 39 HArv. L. Rev. 725 (1926).

${ }^{9}$ Fowler, A Psychologidal Approach to Procedtural Reform, 43 YALE L. J. 1254 (1934); authorities cited note I supra. 
therefore, is an event in American judicial history. Interest in it in the states, with a view to its possible emulation, makes desirable some account of the way it occurred, and the teachings it may offer for other attempts.

In a brief survey it will not be possible to discuss or emphasize all the interesting problems to which the federal experience has brought light and understanding. I shall limit myself in the main to the reform of civil procedure, making only incidental references to the more recently achieved reform of criminal procedure. My experience and acquaintance has been with the former; and this surmounted the original obstacles and smoothed the way for the latter. But no invidious comparison is suggested; it is the crowning glory of the federal reform that it has been so thoroughly and effectively extended throughout the whole system. ${ }^{3}$ Further, I shall attempt a brief history of the reform movement against the background which made it inevitable and the obstacles necessary to be overcome, the actual experience of drafting and promulgating the rules, some of their more important characteristics, and finally the lessons we may learn from them as to future reforms elsewhere. My own participation in the agitation for the change, particularly for the union of law and equity, and in the drafting of the rules, as reporter and member of the Advisory Committee, makes me hardly an impartial observer. But even though my own enthusiasm for the rules may thus require some discounting, the course of judicial and professional opinion and decision appears to demonstrate the success of the reform so thoroughly that I think we may take it as accepted fact in our further discussion of reasons and consequences. ${ }^{4}$

\section{Early Federal Procedure and the Struggle for the Rule-making Authortty}

The procedure in the federal courts, like those courts themselves, represented a compromise of views upon the part of our founding fathers. Differences in view between the nationalists, desiring the support of a strong court system for a central government, and the federalists, desiring only a generally loose federation of independent states, were settled by authority to the Congress to establish trial courts of definitely restricted jurisdiction. And this authority was only sparingly exercised for many years; thus the general grant of jurisdiction over federal questions dates only from 1875.5 Meanwhile, not unnaturally the procedure in actions at law was

\footnotetext{
'For references see Dession, The New Federal Rules of Criminal Procedure: I, 55 YALE L. J. 694 (1946), with bibliography 697, 698; II id., 56 Yale L. J. 197 (1947); Federal Rules of Crimanal. Procedure, with Notes and Institute Proceedncs (N. Y. U. School of Law, 1946), with bibliography 306-308; Strine, The New Federal Criminal Rules in Action, 8 FED. B. J. rgo (I947); Freed, T\%e Rules of Criminal Procedure: An Appraisal Based on a Year's Experience, 33 A. B. A. J. Ioro (1947).

- In this article $I$ have made frequent use of the material $I$ have presented in CLark, Code Pleadivc (2d ed. 1947) passim and particularly at 23-45, 50-7I. Hence for the sake of brevity, and to avoid unnecessary duplication, I have limited many of my references in the footnotes below to citatidn of this book, instead of repeating the fuller documentation there given.

${ }^{5}$ Clark and Moore, $A$ New Federal Civil Procedure-I. The Background, 44 Yale L. J. 387 (1935); Warnen, Federal Process land State Legislation, I6 VA. L. Rev. 42I (1930); Clark, Powen of the Supreme Court to Make Rules of Appellate Procedure, 49 HARv. L. Rev. 1303 (1936); x MOORE, FederaI. PrACTICE ro9, 476, 502 (1938).
} 
made to conform to that of the state courts where the federal courts sat. Earlier this was as of stated points of time necessarily already past at the time of the enacting statutes; but under the famous Conformity Act of 1873 , there was established the principle of continuing conformity "as near as may be" to the local practice of the state wherein the federal court was sitting. ${ }^{6}$ Though this avoided the earlier diffculty of applying often a procedure already superseded locally, it was highly unsatisfactory. Federal jurisdiction and substantive law required a specialized approach in any event. This specialization was increased by continuing reforms by Congress of details of procedure covering matters all the way from leave to amend to the filing of equitable defenses. Such a combination of required diversity, superseded in many details by an imposed uniformity, resulted in unique features from district to district, so that federal practice became a matter for the expert, and for the local expert at that. As procedure became more and more simplified in many of the states the demand for reform became insistent. ${ }^{7}$

Meanwhile there was at hand in the federal courts of equity an outstanding example of a contrary practice. The conformity principle had not reached to chancery procedure, partly because of its lessened importance, or nonexistence, partly because of the tradition of court control of chancery practice in England. Hence by their very unobtrusiveness these courts fared better in the federal system than did the courts of law. ${ }^{8}$ The Supreme Court began modestly to provide limited rules, which were added to from time to time, so that the principle of court control came to be embodied in the statutes. Under the statutory control granted, the Supreme Court had drafted the Equity Rules of 1912, which provided an advanced and flexible practice following English models. The contrast between the uniform equity rules of simple character and the complexities of conformity at law was therefore most striking. In I $\mathrm{I}_{5}$ Congress passed the Equitable Defense Statute, providing for the pleading of equitable defenses in actions at law; and this law was supplemented by court rules providing in substance for the transfer of cases between the equity and law sides of the single federal district court. The whole ancient dichotomy of law versus equity had become more a matter of form than of substance. Yet the problems of form were obtrusive, so much so that many cases seemed to indicate as a consequence of the continued separation only the necessity of vindicating purely formal rules. ${ }^{9}$

Sporadic pressure for reform received an impetus with the organization of the American Bar Association in 1878 , which almost at once turned its attention to the problem. Thus as early as 1886 , David Dudley Field was urging it to act. ${ }^{10}$ The

${ }^{\circ}$ Clark, Code Pleading 31-34 (2d ed. 1947); Tolman, The Origin of the Conformity Idea, lts Development, the Failure of the Experiment, etc., 23 A. B. A. J. 971 (1937).

"Ibid.; authorities cited note 5 stupra.

${ }^{8}$ Clark and Stone, Review of Findings of Fact, 4 U. OF CH. L. REv. 190, 192-199 (1937); note 5 supra.

${ }^{\circ}$ Clark and Moore, op. cit. supra note 5; Clark, The Challenge of a Netv Federal Civil Procedure, 20 Corn. L. Q. 443 (1935).

${ }^{10} 9$ A. B. A. ReP. 503, 55I (1886); cf. 10 id. at 317 (I887); il id. at 63, 79 (188); ClaRk, CODE Pleading 34 (2d ed. 3947 ). 
movement achieved definite form in I9I2 when the Association created its Committee on Uniform Judicial Procedure to secure authority for the drafting of uniform rules by the Supreme Court. Its chairman for many years, Thomas W. Shelton of Norfolk, Virginia, was a leading factor in dramatizing the cause, even though he did not live to see the consummation of his efforts. ${ }^{11}$

The initial program embraced only procedure in law actions, supplementing existing rule-making authority in equity. But in I922 the Association, under the urging of Chief Justice Taft, added another section to its proposed bill to provide for the uniting of the law and equity procedures. ${ }^{12}$ This was a wise and necessary step. The support of the great code states could hardly be secured for the comparatively minor reform of separate, even though improved, procedures, in two opposing federal systems. Unfortunately, as we shall see, the drafting skill shown in this reform did not equal the zeal of the reformers; the second section remained rathet an addendum than an integrated part of the entire bill, and the conflicts and omissions between the sections have caused and are still causing some problems in continuing rule making after the achievement of the initial reform. ${ }^{13}$

Though the committee enlisted the support of many of the most distinguished leaders in the profession, there was determined opposition. Its spearhead was the late Senator Walsh, member of the powerful Senate Judiciary Committee and himself an antagonist of fiery and sincere persistence. His was the fear of a complicated metropolitan procedure to be foisted upon what he considered the simple practice known in the western states. Actually there was some ground for his fear; the Senator could point to the complications and vicissitudes of New York practice as proving his point. But his twin premises, that conformity could achieve for the federal courts the simpler practice of his own Montana while uniformity must mean the diversities of New York practice, were hardly justified, as events were later to prove. Nevertheless his long and dramatic opposition did have the effect of highlighting the need of a simple system in order to gain respect and support for the change. Thus it aided in assuring a better result when the reform finally came. ${ }^{14}$

With the death of Mr. Shelton in I930 the reform movement, so far as the Bar Association was concerned, lost its vitalizing force. The committee was kept alive for a couple of years until, on the report of a district judge, himself opposed to change, it was allowed to disband on the ground that further effort would be use(1938).

${ }^{21}$ Clark, Code Pleading 35 (2d ed. 1947), with citations to committee reports; 24 A. B. A. J. 97

II Now $\$ 2$ of the enabling act, 48 STAT, I064 (1934), 28 U. S. C. \$723c (I940); the earlier provision for rule making at law became $\$ \mathrm{I}, 28 \mathrm{U}$. S. C. $\$ 723 \mathrm{~b}$. See Taft, Three Needed Steps of Progress, 8 A. B. A. J. 34, 35 (I922); Taft, Possible and Needed Reforms in Administration of lustice in Federal Courts, 8 A. 'B. A. J. 601, 604, 607 (1922); 47 A. B. A. REP. 250, 259-261, 268 (1922); cf. also his suggestion in I9I4, 39 A. B. A. Rep. $38 \mathrm{I}$.

${ }^{13}$ See infra; Clark, Code Pleading 4r-45 (2d ed. 1947).

${ }^{14}$ See committee reports by Senator Walsh cited by Clark and Moore, supra note 5; Walsh, RuleMaking Power on the Law Side of Federal Practice, 13 A. B. A. J. 87 (1927); Clark, Code Pleading 35,36 (2d ed. 1947). 
less. In I933 Senator Walsh died suddenly just before he could assume the duties of the attorney generalship in President Roosevelt's first cabinet. His successor there was Homer Cummings of Connecticut, who undertook a program of reform involving both the civil and the criminal law and, in the course of it, in March, 1934, caused to be introduced the identical bill which the American Bar Association had so long and so unsuccessfully fostered. Within the short space of ninety days he had, practically singlehanded, secured the adoption of the measure, on June 19, 1934. His has been a proper pride in so quickly accomplishing a reform beyond the reach of the organized Bar, and an opportunity, of which he has not failed to avail himself, of chiding the distinguished lawyers upon their failure to realize the importance of political skill in effecting reform. ${ }^{15}$ Doubtless here is one of the most important lessons for emulators of the federal success.

II

\section{The Drafting of the Rules}

The first steps in executing the statute were undertaken by Attorney General Cummings, who appointed a staff and supervisory committee with the announced objective of drafting uniform rules at law corresponding to the already existing equity rules. But this seemed only a partial realization of what had become a setted program since. Chief Justice Taft's inspiring leadership of the movement in 1922, and there was agitation for the more extensive reform of the union of law and equity, so familiar a part of state code procedure. ${ }^{16}$ This appears to have been persuasive to the Supreme Court, for the next year it decided on two most important principles: (I) that it itself would accept the responsibility given it by the statute and would undertake the reform, acting upon the advice of an Advisory Committee which it would appoint, and (2) that it would adopt the more complete program of uniting the law and equity procedures. ${ }^{17}$ It immediately asked former Attorney General William D. Mitchell to serve as chairman of its proposed committee and through him received suggestions for the membership of the committee, to include both active federal practitioners and law school teachers. On June 3 , 1935, the Court embodied its program in a formal order appointing a committee of fourteen, representing all parts of the country and the diverse shades of experience just indicated. 18

\footnotetext{
${ }^{15}$ See the several addresses cited in Ceask, Code Plesdivg 35, 36 (2d ed. 1947), which gives references for this history; Cummings, Modernizing Federal Procedutre, 24 A. B. A. J. 625, 885 (1938). The statute is cited in note 12, supra.

${ }^{10}$ Including the articles by Professor Moore and the author cited in notes 5 and 9, supra. As an item of unpublished history, it may be stated that a letter from former Attorney General Mitchell to the Chief Justice, stating most cogently the reasons for the full reform, undoubtedly helped mightily in persuading the Court both of the desirability of the full reform and of Mr. Mitchell's ability to shape its course. The ultimate success of the reform was due in no small measure to his unique contribution of informed and forceful leadership as chairman of the Court's Advisory Committee.

${ }^{17}$ First announced by the Chief Justice at the meeting of the American Law Institute, May 9, 1935, 55 Sup. Ct. xxxv-xxix (1935), 21 A. B. A. J. 340 (1935).

18295 U. S. 774 (1935); see also 297 U. S. 731 (r936).
} 
Since that initial step the Court has assumed all responsibility for the task, and has acted assiduously to show its recognition of its statutory obligation. Immediately it caused all work to be removed from other governmental departments, and the office of the committee to be located in the Supreme Court building itself. It has supervised the work of the committee in all details, including the appointment of research assistants and the expenditure of the appropriations made by Congress for the purpose. And its final consideration has been more than perfunctory, as is shown by its elimination of certain proposed rules in its original action in 1937 and its order approving amendments in $19466^{19}$ The same sense of responsibility was shown by the Court in connection with the federal rules of criminal procedure authorized by later acts of Congress. Following the model of the civil reform, it appointed an advisory committee, which after some years' effort carefully prepared a report in the light of professional criticisms and the best experience and advice available. This the Court adopted with some modifications in I944, and the criminal rules became finally effective March 2I, $1946 .^{20}$

The leadership of the Court has been invaluable in securing the success of the rules. No other professional group in the federal system possesses a like prestige or a like power to give vitality to such a reform. Suggestions that rule making be placed under the aegis of other bodies, of which almost the only one available appears to be the Conference of Senior Circuit Judges, would call for the sacrifice of this stimulus and this guarantee. This apparently has been the conviction of the great majority of the justices, though Justices Brandeis, Black, and Frankfurter have declined to concur in certain of the rule-making orders. The objections were made articulate by Justice Frankfurter in his memorandum with reference to the rules of criminal procedure. ${ }^{21}$ They concerned the capacity of the Court itself, and suggested that the justices lacked both time and expertness for the task. But the device of an advisory committee would appear to supplement adequately the Court's own facilities for expert study and knowledge by experience; and this seems to be the teaching of experience. The very success of the experiment to date is proof that the method is sound. Justice Frankfurter's more recent action in approving amendments to the civil rules "essentially because of his confidence in the informed judgment" of the Advisory Committee appears to be a recognition of this fact. ${ }^{22}$

\footnotetext{
${ }^{20}$ In its original order, Dec. $20,1937,302$ U. S. 783 (1937), the Court omitted two proposed rules, as to one of which the committee had expressed some doubt of the Court's power to act. I MOORE, Federal. Practice 44-48; 2 id. at 2500-250x, 3 id. at 3073-3076, 3690-3692 (r938). In its later order, Dec. 27, 1946, 329 U. S. 843 (1946), it approved all the recommended amendments except three, which concerned matters then before the Court. See note 27, infra.

${ }^{20}$ Order of Dec. 26, I944, 323 U. S. 821 (1944), as to the rules reported to Congress; order of Feb. 8, 1946, 327 U. S. $825(1946)$, for the rules not so reported. The anomalous distinction thus required in adoption of the same set of rules is discussed note 29 , infra. See also authorities cited note 3, supra.

${ }_{21} 323$ U. S. 821-823 (1944). Compare critical comments in 3 I A. B. A. J. 136, I63 (1945), and by Messrs. Cummings, 31 A. B A. J. 236, 238 (1945), and Dession, stpra note 3, 55 YAlE L. J. 694, 698 (1946).

329 U. S. 843 (1946); compare also the Court's order of Jan. $x 7,1938,302$ U. S. $783-785$ (1938), expressing appreciation of the committee's work and of the rules as drawn. These orders, together with that of Feb. 8, 1946, supra note 20, were all actions of the entire Court.
} 
Perhaps a further assurance that the work of rule making will be at least devotedly performed, and with all the competence that the individuals engaged upon it can bring to the task, is found in the undoubted interest in the work. As a member of the committee, I can testify that no professional activity was ever more stimulating, and none approached it in arousing the excitement of all participants. Usually a drafting process calls for tedious effort where the labors of only one or a few individuals come to be a dominating force. But this was not the case here. All lawyers love to battle over court procedure, and the high nature of the responsibility placed upon the individual members heightened the interest. Long hours and lengthy days of conference seemed to cause no abatement of enthusiasm. And there is no doubt that the members of the committee grew in knowledge and understanding of the subject, and in unity of view, as the work progressed. At first the widely divergent views, based on the varying backgrounds and types of experience represented, seemed to make final agreement doubtful. But increasingly the fundamental similarities of objectives of all conflicting systems and the lessened importance of the surface differences were borne in upon the committee. Moreover, the program of submitting drafts of rules to the profession for criticism and suggestion proved its value, for when the time for final decision arrived the committee was fortified by a pretty wide view of the professional thinking upon the various topics. And so the committee achieved the further unique result of not merely apparent, but real, unanimity in its various reports. ${ }^{23}$

In drafting the original rules the committee's activities continued from its organization in June, I935, until its report to the Court in the fall of 1937. A reporter's staff for research and drafting was immediately organized, and tentative drafts were presented to the committee at regular conferences beginning in the fall of r935. The committee with the Court's approval caused to be printed for comment and criticism a "Preliminary Draft" in May, I936, and a "Report" in April, I937; then it submitted its Final Report to the Court in November, 1937. ${ }^{24}$ The Court approved the report, with certain limited exceptions, on December 20, 1937, and the rules as adopted were presented to Congress by Attorney General Cummings at the Court's request at the opening of the Seventy-fifth Congress. No opposing action having been taken by that body, the rules became effective, according to their terms, three months after adjournment, or on September $x 6,1938 .^{25}$

In $x 939$ the Court made the rules applicable, so far as not inconsistent with statutes, in bankruptcy and copyright matters; it also asked the committee to sub.

${ }^{23}$ The only noted (and actual) case of dissent, Report of Proposed Amendments 46 (June, 1946), was that involving the much controverted question of discovery of lawyers' files, by one member, who, because of illness, had not had the benefit of the thorough discussion and exploration of the issues at the committee's meetings and who died before the Court acted as pointed out in notes 27,48 , infra.

${ }^{24}$ For references to these documents and the various articles upon and discussions of the drafts, see Clark, Code Plending 36,37 (2d ed. 1947), and a series of articles by the writer in 22 A. B. A. J. 447,787 (1936), 23 id. at 976 (1937), 23 WAsh. U. L. Q. 297 (1938), 15 TENN. L. Rev. 551 (1939).

${ }_{25} 302$ U. S. 783 (1937), supra note 19; 308 U. S. $645-788$ (1938), giving the text of the rules. For the discussions in Congress, see Clark, Code Pleading 37, 38 (2d ed. 1947). 
mit amendments. Moreover, the Court, upon the committee's recommendation, adopted a slight change in a single rule, which became effective the following year, after it had been reported to Congress, constituting a precedent both for the authority to amend the rules as needed and for the procedure thereunder. ${ }^{26}$ In 1942 the Court reconstituted the committee to consider the recommendation of amendments; and after several conferences and the submission of two preliminary drafts for criticism in accordance with the procedure originally established, the committee presented its report to the Court in the fall of 1946 , recommending a series of amendments. Again the Court adopted all the proposals except three, which involved issues before the Court in pending cases. ${ }^{27}$ The amendments were reported to the Eightieth Congress at its opening session in January, 1947. Since no move has been made in Congress to question them, they will become effective, acccording to their terms, three months after Congress has adjourned. This date, left somewhat in doubt when Congress first "adjourned" to January 2, I948, unless sooner recalled by its majority leaders, was made certain when, after the resumption of the session in November, 1947, both houses adjourned sine die on December r9, 1947. ${ }^{28}$

That there may be such a prolongation of the rule-making process, for reasons of state entirely unconnected with it, is a striking demonstration of its present unfortunate rigidity under the enabling act as currently construed. The writer with others has urged that the requirement for reporting to Congress found in the Act's second section applies only to the one matter there covered, namely, the union of law and equity, and that, this once having been achieved, further changes in the rules would be subject only to the normal procedure of the first section, i.e., promulgation of the rules by the Court six months before they become effective. As a gesture of courtesy the reporting to Congress by the Court may be desirable; and if its formal statement as a legal requirement is thought necessary, a simple requirement for such reporting two or three months before the effective date of the rules would be quite adequate. But the presently assumed requirements are a deadening influence upon the process. The holdings that the rules must be reported at the opening of a regular session of Congress (and that, too, by the Attorney General, who has not participated in the rule making in any way) and that they shall remain there until

${ }^{23} 305$ U. S. 68 I, 698 (1939); 307 U. S. 652 (I939); 308 U. S. 64 I, 642 (I939).

${ }^{27} 329$ U. S. $839-878$ ( 1947 ), giving the text of the amendments; for the order requesting the members of the committee again to serve, see 314 U. S. 720 (1942); and compare Clark, The Proper Function of the Supreme Court's Federal Rules Committee, 28 A. B. A. J. 521, 525 (I942). Of the three amendments not approved, one involving discovery of lawyers' files was substantially incorporated in the Court's later decision, cited note 48 , infra. Decisions involving the substance of the other two interpreted existing law as being contrary to the committee's recommendations. Anderson v. Yungkau, 329 U. S. 482 (1947); Cone v. West Virginia Pulp \& Paper Co., 330 U. S. 212 (1947).

${ }^{28} 93$ Cong. Rec. I 1843 , II 888 (Dec. I9, 1947). The three months' delay after adjournment is provided by the amendment which forms Rule 86(b), 329 U. S. 839, 875 (I947), 6 F. R. D. 249, making the effective date March 19,1948 , as was forecast in a learned memorandum by the Legislative Reference Service of the Library of Congress for the Senate Committee on the Judiciary, to be found in 93 Cong. Rec. 10696 (Nov. 17, 1947), and in a Committee Print, Dec. $x$, I947. In accord are Ashley v. Keith Oil Corp., ro Fed. Rules Serv. 86b.21, Case I (D. C. Mass. 1947); United States ex rel. Hirshberg v. Malanaphy (C. C. A. 2d Jan. 12, 1948) (without opinion). 
the close of Congress mean, as events have developed in recent years, that the rules must be reported early in January and become effective only in March or April of the following year. The reporting date is a diffcult one for the profession, the Advisory Committee, and the Court, for all these bodies are likely to be heavily engaged in performance of their more immediate obligations upon return from the long summer vacation in the fall. To forestall unavoidable delays the deadline for action should be set for May or June, rather than for late December. Moreover, the long delay in the effective date of even the simplest amendments-thus requiring from two to five years-substitutes rigidity for flexibility in control of rule making. States which have looked with favor upon federal rule making should be warned against the dangers of accepting the enabling act in toto. ${ }^{29}$

The nature of the amendments which were adopted is in itself important testimony to the success of the original rules and their ready acceptance by the profession. For the amendments made no major change in the fundamentals of practice. Except for a few changes, such as the one which reduced the time of appeal from three months to thirty days, they were designed only to clarify the original purpose and to explain or amplify that purpose. Almost a decade of experience had shown no fundamental weakness in the system established. ${ }^{30}$

\section{III}

\section{SUCCESS OF THE RULES}

The success of the new system thus established is thoroughly conceded. In the light of the opposition to such reforms in the past, and the often successful efforts to obliterate their effect, the universal chorus of approval is quite phenomenal. Decisions, texts, articles, addresses, law school courses-all attest to this. Most important are the activities of the courts themselves. Here the application of the rules by the judges has been uniformly enthusiastic. Universally the courts have expressed the intent of carrying out the principles of simple, effective procedural control stated in the rules themselves. Decision after decision reiterates this conception. Even if we might find occasion here and there to challenge a particular result, nevertheless the general good will of the bench towards the system is thoroughly demonstrated. Many judges of long experience have commented especially upon not merely the worth of the rules themselves, but the invigorating spirit they have aroused in the

${ }^{29}$ For discussion with citations, see Crark, Code Pleading 4I-45 (2d ed. I947). The situation as to the rules of criminal procedure is particularly anomalous, since these rules are authorized by several statutes conflicting in this aspect. Clark, Code Pleading 45 (2d ed. 1947). See also 3 Moore, Federai. Practice 3448-3452; Armstrong, Proposed Amendments to Federal Rules for Civil Procedure, 4 F. R. D. 124, 137 (1946); of. Sibbach v. Wilson \& Co., 312 U. S. I, 15, 18 (1941); 83 Conc. Rec. 12841-12842 (1938). For the contretemps as to the effective date of the recent amendments, see note 28 supra.

${ }_{80}$ This is the tenor of the comment upon the amendments, particularly in the articles by ex-President Armstrong of the A. B. A., 5 F. R. D. 339, 359 (1946), 28 U. S. C. $5 \$ 721-723$ (1947 Spec. Pamphlet), also in ${ }_{4}$ F. R. D. 124 (1946), 3 I A. B. A. J. 497 (1945); for other citations, sce Clukk, Code Pleadivo 39 (2d ed. 1947). 
judiciary. This is the most substantial, as it is the most heartening, achievement of the reform. ${ }^{31}$

Beyond the actual decisions in the cases is the published comment to the same effect. Federal procedure is now taken as basic in law courses, and the teaching materials are shaped to it. The amount of literature stimulated by the reform, as shown by the published bibliographies, almost overwhelms. ${ }^{32}$ 'Among encomia we find such statements as that the rules represent "one of the greatest contributions to the free and unhampered administration of law and justice ever struck off by any group of men since the dawn of civilized law,"33 or the more restrained statement from a distinguished jurist of many years' experience in a large metropolitan area, "I have yet to note an instance in which they have been found lacking." ${ }^{34}$ The late Chief Justice Stone's own enthusiastic comments pictured the system as "concise, simple, adaptable, and efficient," and the rules as "highly successful in operation." ${ }^{35}$

Direct criticisms of the system as a whole, almost nonexistent at the beginning, seem not to be repeated now. ${ }^{36}$. There are, of course, some disputes over particular rules; and the preference still considerably expressed for local procedures with "improvements" is, so far forth, a refusal to accept the federal system completely. Both of these far from unnatural developments are discussed below because of their importance to the future spread of the system. But as to the first, it should be pointed out that the problems arise mainly as to the newer procedural devices, such as discovery of lawyers' files, summary judgments, or third-party practice, rather than the fundamentals of the system. ${ }^{37}$ And as to the second, the view usually rests upon an instinctive but, it is believed, not thoroughly analyzed reaction that for the most part accustomed state procedure is more adapted to the local bar than would

\footnotetext{
${ }^{32}$ Specific decisions are far too numerous to cite; the pages of the successive volumes of the Federal Rules Decisions and the Federal Rules Service abound in illustrations; these volumes, especially the former, contain numerous articles and addresses of like tenor by federal judges. An early expression of this point of view is found in S, E. C. v. Timetrust, Inc., 28 F. Supp. 34, 4I, 42 (N. D. Cal. 1939). At times in the early decisions, this point of view was expressed to lead to a result contrary to the more settled conclusion as later developed. Cf. Teller v. Montgomery Ward \& Co., 27 F. Supp. 938 (E. D. P2. 1939); Westland Oil Co. v. Firestone Tire \& Rubber Co., 3 F. R. D. 55 (D. N. D. 1943); CLARK, CODE Plendivo 342-344 (2d ed. 1947).

"There are already many extensive bibliographies of articles; for citations see Clank, Code Pleading 39, 40 (2d ed. 1947). Among school casebooks emphasizing the rules, sec Pike, Cases akd Other Materials on New Federal and Code Procedure (1939); Dobie and Ladd, Cases and Materílals on Federal Jurisdiction and Procedure (1940); McCormick and Chadbourn, Cases and Materials on Federal Courts (1946); Clark, Cases on Pleading and Procedure (2d. ed. 1940).

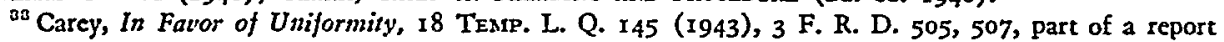
showing strong support for the rules among lawyers, law teachers, and bar associations.

"Chesnut, Improvements in Isdicial Procedure, I7 Cons. B. J. 238, 243 (1943).

IE I THE RECORD I44, I50 (1946). See also Justice Burton's address before the American Bar Association, 33 A. B. A. J. I099, I166, 1167 (1947).

De Thus among early critics were McCaskill, One Form of Civil Action, But What Procedure, for the Federal Courts, 30 ILx. L. REv. 415 (1935), whose objections may perhaps be continuing; cf. McCaskill, Against Uniformity, 8 TEMP. L. Q. 145, 3 F. R. D. 505, 508 (1943), and note 43 infra; and Judge Fee, The Proposed New Rules for Uniform Procedure in the Federal District Courts, 16 OrE. L. Rev. 103 (1937); but Judge Fee's decisions applying the rules have been quite in their spirit.

${ }^{87}$ Discussed briefly infra.
} 
be a complete reform. ${ }^{38}$ Occasionally, however, there is added the thought that the mere number of federal rules decisions suggests a failure of the rules to solve the "pleading problem"39 - a suggestion which overlooks the vast number of merely confirmatory decisions by judges imbued with the new spirit and the American business ingenuity which makes any form of judicial utterance, even on a minor procedural point, a valuable commercial asset.

If, however, this reform is to become a workable example for other jurisdictions, it is necessary to analyze and understand the reasons which have led to its ready acceptance in the federal courts, and which may operate either not at all or with lessened weight as support of state acceptance of a like system. But in any event many may be duplicated with foresight and planning. It seems well therefore to devote some attention, first, to the characteristics of the rules which have brought forth so favorable a reception and, second, to the details of the federal rule-making process in order to envisage those features which may be considered unique and those which may well be duplicated elsewhere.

\section{IV}

\section{Characteristics of the Rules as Adopted}

The cornerstone of the new reform is a system of simple, direct, and unprolonged allegations of claims and defenses by the litigants, resting, in turn, upon a blending of the old law and equity systems and upon the concept of a civil action inclusive in content of all points of dispute between the parties. This keys the entire reform. It is in effect a de-emphasis upon pleading as a controlling element in decision and a subordination of procedure to its proper position as an aid to the understanding of a case, rather than a series of restrictions on the parties or the court. ${ }^{40}$ It was achieved by employing the more tested devices under the best of English and American practice, by discarding some of the ancient circumlocutions of statement, by limiting the pleadings in number as well as in character and detail, and finally by a simple set of forms "intended for illustration only," but designed, as the rules themselves

${ }^{38}$ This appears in the articles which have appeared supporting limited reform in states such as lowa, Missouri, and Texas, discussed infra, or in the article by Professor Rothschild and the committee report cited note 39, infra. I have stated my criticisms of this approach elsewhere: Dissatisfaction with piecemeal Reform, 24 J. AM. Jud. Soc'x $12 \mathrm{x}$ (1940), The Texas and the Federal Rules of Civil Procedure, 20 Tex. L. Rev. 4, 5 (I94r), and my Code Pleading 47-49, 5I-53, 63, 64 (2d ed. 1947).

${ }^{39}$ Rothschild, Reformulating the furisdiction of the Court of Appeals, 13 Brooksyn L. Rev. 14, I6, I7 (I947); Rep. of Committee to Cooperate with the Judicial Council, 69 N. Y. ST. BAR Ass'N Rep. 342, 351-367 (x946), which reflects an unusual satisfaction with the much debated and debatable New York practice; but see the able Memorandum on Proposal to Empower the Court of Appeals to Make Rules of Procedure for the Courts of the State of New York, 2 THE REcond 12-26 (1947), which is signed on behalf of four committees-for the American Bar Association, the Citizens Committee on the Courts, and the infuential city and county bar associations.

50 This philosophy has been stated in my Simplified Plending (A. B. A. Jud. Adm. Monographs, Ser. A, No. x8), Handbook Nat. Conf. Jud. Councils 136 (I942), 2 F. R. D. 456, 27 Iowa L. Rev. 272 (r942), and The New Federat Rules of Civil Procedure: The Last Phase-Underlying Philosophy Embodied in Some of the Basic Provisions of the New Procedzure, 23 A. B. A. J. 976 (1937), ConE Pleading 56-58 and c. 4 (2d ed. 1947), and cf. Hunter, One Year of Our Federal Rules, 5 Mo. L. Riev. I (1940); Dioguardi v. Durning, r39 F. 2d 774 (C. C. A. $2 d$ 1944). 
state, to indicate "the simplicity and brevity of statement which the rules contemplate." "11 With the illustrations provided by the forms it was not possible for a court to conclude that the old detailed allegations of some of the code systems could be a requirement under the new practice. Possibly the most interesting example is the form of a complaint for negligence against an autoist which comes directly from a Massachusetts statutory form based, in turn, upon the simple allegations of the old action on the case. Notwithstanding its historical background some attack was made upon it as being unrecognized in American law. But under the new rules, as under the old practice, it has proved quite adequate and effective. ${ }^{42}$

A necessary corollary to this system was, of course, the union of law and equity. If two separate systems, at war with each other, were to be retained in the federal courts, it was obvious that directness of procedure would be impossible. But so easy was the acceptance of this principle of union, so little problem has it actually presented under the rules, that the many doubts expressed before their enactment, even questions of constitutionality, seem now merely relics of antiquity. Perhaps nowhere has a complete acceptance of the rules been more completely demonstrated than in the entirely unruffled application of this fundamental principle, which at an earlier time would have been necessarily the most novel and debated feature of the new reform. ${ }^{43}$

The all-inclusive civil action has also been demonstrated as an obvious and desirable feature of modern reform. But it is carried further under the new rules in general than even in the more advanced state codes. With the de-emphasizing of particularized pleading there remained no reason why all claims between litigants could not be desirably adjusted at one time. If necessary or convenient, separate stages of trial could be ordered; but such matters could properly be left to the discretion of the trial judge. Of course the exigencies of federal jurisdiction may pre-

\footnotetext{
${ }^{21}$ Rule 84, Fed. R. Crv. P.; cf. Appendix of Forms 1-27; Committee's Note to amendment to Rule 84, Report of Proposed Amendments i18, il9 (June, i946); Clark, Code Pleading 239-245 (2d ed. 1947).

"Fed. Form 9 from Mass. Gen. Laws, c. 231, \$147 (1932); Williams v. Holland, Io Bing. II2, I3I Eng. Rep. 848 (C. P. 1833); 2 ChItTy, Plesding 529 (7th ed. 1844). For supporting authorities see Clark, Code Pleading 243, 244, 300, 301 (2d ed. I947).

${ }^{43}$ See, e.g., Hurwitz v. Hurwitz, 136 F. 2d 796 (App. D. C. 1943); Groome v. Steward, I42 F. 2d 756 (App. D. C. r944); Beaunit Mills v. Eday Fabric Sales Corp., I24 F. 2d 563 (C. C. A. 2d r942); One Form of Action, 32 A. B. A. J. 408 (I946); Pike and Fischer, Pleadings and Jury Rights in the New Federal Procedure, 88 U. of PA. L. Rev. 645 (1940); Holtzoff, Equitable and Legal Rights and Remedies under the New Federal Procedare, 31 CaLIF. L. Rev. 127 (1943); Morris, Jury Trial Under the Federal Fusion of Law and Equity $20 \mathrm{TEx}$. L. Rev. 427. (1942); but see McCaskill, Jury Demands in the New Federal Procedure, 88 U. of PA. L. Rev. 35 (1940), and note 36, sttpra. Earlier there had even been claims of unconstitutionality, effectively answered by Dean Pound, Law and Equity in the Federal Courts, 36 A. B. A. REP. 470, 73 CENT. L. J. 204 (19II); Chief Justice Taft, supra note 12; and others cited in Clark, Code Plending 32, roz (2d ed. 1947). The nostalgic dictum for the old separation (inconsistent with the court's decision) expressed in Bereslavsky v. Caffey, r6i F. $2 d$ d99 (C. C. A. 2d 1947), is unusual in the federal decisions; but the persistence of support for inconsistent and warring procedures in states such as New Jersey, once again in the throes of constitutional reform, does seem remarkable. Cf. examples cited in Clark, Divided Law and Equity Jurisdiction, 28 J. Ax. Jud. Soc'y 29 (1944), and 67 N. J. L. J. 85 (1944). See, in general, Clark, Code Pleading 22, 28, 32, 40, 78-127 (2d ed. I947); also note 62 , infra.
} 
vent in practice as complete an application of this principle as is possible in the state courts. Nevertheless the principle has shown its effectiveness in federal operation. There all claims or counterclaims or cross claims between the parties may be joined in the one action without reference to the "nature of the cause of action" or other ancient forms of restriction. As concerns multiple parties, there may be extensive joinder of many plaintiffs or many defendants, subject only to the general requirement that there be a common question of either law or fact affecting them: And the system is rounded out by extensive provisions for amendment, adding of claims, and adding, dropping, or intervention of parties. ${ }^{44}$

This, then, is the fundamental background and basic principle of the new system. There have been newer and special devices-discussed below-which have perhaps attracted more attention and more immediate popular interest. But the fact that this system should have gone into operation so quietly and unobtrusively shows how well it was adjusted to both modern needs and modern ideas. The only matters requiring even a period of adjustment before they operated smoothly appear to have been those involving the abolition of the demurrer in favor of the omnibus motion or answer raising all objections at one time and the restrictions set upon the grant of a motion for a bill of particulars. Here, also, the practice has become uniform and effective, even without the aid of the amendments recently adopted which emphasize the original purpose and still further discourage dilatory procedural strategy..$^{45^{\circ}}$ Moreover, however interesting may be the newer procedural devices such as discovery and pre-trial conferences, they would have been limited in scope and effectiveness but for this thorough acceptance of the fundamental objectives of the system. And, as we shall see, not all of these are completely adopted by the courts or have yet achieved their fullest potentialities. Hence we may count it a boon that while they occupy the limelight the main system itself is working its way quietly and unobtrusively into the settled experience and habits of the profession.

Among the newer procedural devices, those designed to develop the issues on the merits quickly, and if possible in advance of trial, have achieved the greatest interest. These are the provisions for discovery, for pretrial conferences, and for summary judgment. The discovery provisions call for the taking of depositions or the answers

"These provisions appear in FED. R. Civ. P., 2, 13-15, 18-25 42, 54, and are discussed in Chank, Code Pleading 58, 65, 144-146 and cc. 6, 7, 10, I2 (2d ed. 1947). Pleas for yet more extensive joinder appear in Recent Trends in loinder of Parties, Causes, and Counterclaims, 37 Col. L. REv. 462 (1937), Blume, Scope of a Civil Action, 42 MrCH. L. REv. 257 (1943), Blume, Free Joinder of Parties, Clains, and Cozinterclaims (A. B. A. Jud. Adm. Monographs, Ser. A, No. I1), Handsook Nat. Conf. Jud. Councirs 77, 2 F. R. D. 250 (1942), and elsewhere; indeed, some modification of ancient joinder restrictions seems one of the first steps of state reform discussed infra. But still more notable is "the immense travail that our own procedure has undergone to reach, in its more progressive forms, a result not very far distant from that which the gentler evolution of procedurhl institutions, since the reception of the Roman law, has given to the more advanced codes of the Continental countries." Millar, The Joinder of Actions in Continental Civil Procedure, 28 ILL. L. REv. 26, 177 (1933).

${ }^{45}$ See Advisory Committee's notes to proposed amendments to Rules $12(\mathrm{~b})$ and 12(e), Reporr or Proposed Amendments 11-i7 (June, 1946); and discussion in Ciark, Code Pleadinc 341-344, 540545, 549, 555, 556 (2d ed. 1947), and citations supra note 40. 
to interrogatories or the delivering up of documents, photographs, and the like in all civil actions. Thus simply on notice in a pending suit discovery may be had not merely of potential evidence to be used at trial, but also of testimony reasonably calculated to lead to the discovery of admissible evidence. The objection to the socalled "fishing expedition" is repudiated, and the principle that more is to be gained by knowledge on the part of all litigants of all features of a case than by a surprise attack is now established. ${ }^{46}$

Such a system seems thoroughly desirable as an assisting means to effective disclosure of the truth in any lawsuit. But it does present a problem, not yet thoroughly explored, in the possibility of increased costs, particularly to the poorer litigants, since the taking of a deposition may often involve expenses of travel and of the employment of additional counsel. There have been plans for research in this important field, but as yet we lack sufficient information to determine whether or not the procedure is open to abuse in this regard. ${ }^{4 \tau}$ On the other hand, some more spectacular problems have received unusual attention. Chief among these has been the question of discovery of "lawyers' files," i.e., of materials obtained by the lawyers in preparation of a case. But the Supreme Court seems to have settled the issue in a recent case in which it rejected the extreme claim of complete privilege and, while restricting discovery of such material in the ordinary case, recognized its use in situations where it is necessary to the full development of the facts in a particular case. $^{48}$

The federal rule authorizing district judges to conduct pre-trial conferences with the attorneys in pending cases for the purpose of settling and simplifying the issues has been widely approved and adopted in state procedure. Enthusiasts have criticized the optional character of the rule. But calendar conditions, the necessity of circuit travel, and like local conditions may make it difficult for a judge to meet such assignments. Further, in spite of the undoubted worth of the rule, its operation has not been equally effective with all judges. Some have stressed the bringing about of settlements of cases, a result which can be safely treated only as a by-product of clarification of the issues, not as an end in itself. Many have failed to enter an adequate pre-trial order, definitely settling and recording the matters discussed at the conference; without this the matters are left at large at the trial, and the device has largely failed of its usefulness. This, then, must be considered a worth-while

${ }^{10}$ Hickman v. Taylor, 329 U. S. 495, 507 (1947); Pike and Willis, Federal Discovery in Operation, 7 U. of CHr. L. REv. 297, 303 (I940); Advisory Committee's notes to proposed amendments to Rules 26(b) and 30(b), Report of Proposed Amendments 34-36, 40-47 (June, 1946). The timendment to Rule $26(\mathrm{~b})$ re-enforces the principles originally stated.

${ }^{47}$ A promising investigation of cases in the Southern District of New York, conducted by the New York Law Society, was halted by the war before the stage of publication was reached.

${ }^{18}$ Hickman v. Taylor, 329 U. S. 495, 513 (1947), which refers to "the widespread controversy among the members of the legal "profession" over the problem; this is also brought out in the Advisory Committee's notes, cited in note 46 , supra. While the Court had failed to approve the Committee's proposed amendment to Rule $30(\mathrm{~b})$, commiting the matter to the discretion of the trial judge to prevent hardship or injustice, the result of this case is in substantial accord with the proposal and appears to make amendment unnecessary. 
reform, which must be allowed time to grow into the habits of judges and lawyers before its fullest utility is achieved. ${ }^{49}$

The summary judgment is of more ancient lineage. It was quite fully developed in England and in some of the states, particularly New York, where it appeared as a civil practice rule in rg2r. But the federal procedure does not follow the earlier practice of restricting the remedy to debt and contract claims. It allows such a judgment in any civil action upon a motion supported by affidavits, pleadings, or depositions which show that there is "no genuine issue as to any material fact and that the moving party is entitled to a judgment as a matter of law." Some appellate judges in their anxiety lest a plaintiff be deprived of full opportunity of attempting to prove his case have expressed objection to "trial by affidavits," overlooking the simple justice of affording a defendant protection against the expense and at times cruelty of a long trial on perfectly footless claims. In earlier times some such claims were disposed of on issues of law by the practice of sustaining demurrers. But this placed the emphasis upon pleading niceties, and was at times unduly harsh, but more often merely inconclusive and dilatory. The summary-judgment practice successfully centers attention directly on the merits, and the safeguards placed about it prevent its improper use to shut off trials unfairly or unduly. The appellate courts must of course check any undue assiduity on the part of district judges in applying the rule; but I am bound to say that in my experience, contrary to that asserted by some of my colleagues, the reversals on the whole seem to me to suggest more cases of doubtful, if not downright harsh, results than do the affirmances. But in consequence enough doubt has been developed about the practice-beyond the motions involving relatively clear questions of law alone-to deprive it of its fullest utility as yet.

\footnotetext{
40 There is now considerable literature centering about Rule 16, Fep. R. Civ. P.: Pre-Trial Procedure, Rep. of Pre-Trial Committee of the Iud. Conf. of Senior Circuit Judges, 4 F. R. D. 83-103 (1946); Pre-Trial Clinic, 4 F. R. D. 35-82 (1946); Shafroth, Pre-Trial Techniques of Federal Judges, 28 J. AM. Jud. Soc'y 39 (1944); Laws, Pretrial Procedure under the New Federal Rules, I2 Mo. B. J. 95 (1941); Klitzke v. Herm, 242 Wis. 456,8 N. W. $2 d 400$ (1943); and other references given in Clank, CODE PLEADING 572-574 (2d ed. I947).

${ }^{80}$ Rule 56, FED. R. Civ. P., has been extensively employed, as shown by citations in Clark, Code 'Plending 556, 566, 567 (2d ed. 1947). See generally, Bernard Lloud Shientag, Summary Judgment (I941), a revision of 4 Fond. L. Rev. 86 (1935); and Clark, Summary Judgments (A. B. A. Jud. Adm. Monographs, Ser. A. No. 5), Handbook Nat. Conf. JUd. Councils 55, 2 F. R. D. 364 (1942), 25 J. Axr. Juv. Soc'y 20 (1941). For some differences of view see Arnstein v. Porter, 154 F. $2 d{ }_{464}$ (C. C. A. 2d I946), Clark, J., dissenting; the order of reversal led to a long and expensive trial, with verdict and judgment for defendant, aff'd on appeal, Arnstein v. Porter, 158 F. 2d 795 (C. C. A. 2d 1946), cert. denied, 330 U. S. 851 (1947), where, it is believed, a plaintiff's verdict could not have withstood review. For criticism see 55 Yale L. J. 8 ro (1946); 45 Col. L. Rev. 964 (1945); Werner Ilsen, Federal Rules of Civil Procedure, with Approved Amendments 346 (rev. ed. 1947) ("may well become nothing more than a glorified motion for judgment on the pleadings"); Kennedy, The Federal Summary Judgment Rule-Some Recent Developments, 13 Brookrys L. Rev. 5 (1947); and for differing results by the same judges, see Dixon v. American Tel. \& Tel. Co., 159 F. 2d 863 (C. C. A. 2d 1947); Bernstein v. Van Heyghen Freres Societe Anonyme, 163 F. $2 d 246$ (C. C. A. 2 d 1947), cert. denied, 68 Sup. Ct. 88 (U. S. 1947); Ricker v. General Electric Co., 162 F. 2 d 141 (C. C. A. 2d 1947); and see also Griffin v. Griffin 327 U. S. 220, 235, 236 (1946), and the discussion at the Tenth Circuit Conference as reported in 33 A. B. A. J. III1, 1112 (1947).
} 
Other new procedural devices, concerned particularly with the addition of parties, are perhaps even better known. The use of broad forms of claims in the nature of interpleader, of class actions, of intervention, of the declaratory judgment, has become reasonably well settled. ${ }^{51}$ Perhaps one of the most interesting is the impleader of third parties, the bringing in by a defendant of a party answerable over to him. An attempt was made in the new rules to expand this practice to allow the impleader of a party answerable only to the plaintiff, thus allowing the defendant to force upon the plaintiff an unexpected opponent. In practice this has not proved workable, particularly in the light of the limitations of federal jurisdiction; and the new amendment calls for elimination of this feature of the rules. There is no reason, however, why in state courts of unlimited jurisdiction there should not be further experimentation with this broad form of impleader. ${ }^{.2}$

\section{$\mathrm{V}$}

The Federal Rule-Making Process as Model

Beyond the desirable qualities of the rules themselves, other factors, while making originally for diversity, tended in the long run to make for ready acceptance of federal uniformity. Once authorization of the reform was achieved in Congress, the wide expanse of the federal system and the centralizing influence and prestige of the Supreme Court operated to make the task somewhat easier than it appears to be in the states. It was less likely that opposition would develop in any extensive way among the widely scattered federal practitioners than among, say, the local bar of a state, which can be organized in opposition to a local reform. Both the wide diffusion of the potential opposition and the burden of opposing formal action by the highest court of the land, particularly when that action was based upon the report of a committee acting deliberately with the advice of organized groups and individual members of the profession, presented substantial hurdles. Moreover, the early and long-continued support of the American Bar Association, coupled with the enthusiasm of local bar associations consulted in the drafting of the rules, made this fairly conclusive. ${ }^{53}$ At any rate, opposition, as we have seen, has been practically negligible since the adoption of the rules.

Such conditions, particularly those involving the leadership of the Supreme Court, cannot be completely duplicated in the states. Indeed, in some cases, as pointed out below, perhaps notably Nebraska, developments have taken a contrary

\footnotetext{
${ }^{52}$ Rules 22-24, 57, FED. R. Civ. P., and citations in Advisory Committee's notes to these rules, and in Clask, Code Pleading 333-338, 396-408, 420-423 (2d ed. 1947); of. note 44, supra.

${ }^{52}$ See Advisory Committee's Note to amendment to Rule I4, FED. R. Crv. P., Report of Proposed Amendments 2I-23 (June, I946); 20 So. Calif. L. Rev. 215 (1947); Clark, Code Pleading 408-419 (2d ed. I947).

${ }^{\text {t3 }}$ Clark, A Striking Feature of the Proposed New Rules, 22 A. B. A. J. 787 (1936); Prelimannary Draft of Rules of Crvil Procedure xviii, xix (May, 1936); Report of the Advisory Committee vi (April, 1937); Supreme Court Adopts Rules for Civil Procedure in Federal District Courts, 24 A. B. A. J. 97, 98 (1938). The continued support of the American Bar Association for procedural reform is noted below. See notes 58,63 , infra.
} 
course, leading to the overturning of a state reform once secured. We must concede, for good or ill, the possibilities of swifter mobilization for or against reform on the part of smaller and more integrated units of the profession. But that factor may operate either way. Thus no longer, as in the federal history, should it be necessary to require more than a quarter of a century for the fruition of reform. Moreover, the specific means employed in federal rule making can be usefully adapted to state action and, as experience shows, can form an effective basis for achieving results. First among these is the vesting of the rule-making authority in the highest local court and the drafting of rules under its supervision by as expert a committee as can be secured. This insures both a more thorough job than other sources would produce and also the prestige and backing of the judiciary. ${ }^{54} \mathrm{Next}$, the opportunity given to local groups or individual lawyers to criticize and suggest improvement is also rather fundamental in avoiding errors in draftsmanship and in securing a broad basis of support. ${ }^{55}$ Finally, the greater knowledge now available of the best procedure and the prestige acquired by present-day procedural reforms is a great advantage. It should be utilized to the full in the most effective way possible. In this task, it must be recognized finally that the chief need is one of leadership, as was developed in the federal reform, and that opposition of those used to the old practices must be expected. In matters of political and social policy even democracy needs to be sparked by leadership. Democracy as the sole source of technical procedural rules is not enough. ${ }^{56}$

We shall now turn to some of the pending movements and already achieved reforms in the states. These have surely been substantial and important. One cannot avoid the feeling, however, that as yet full use has not been made of the impetus of the federal reform. True, there has been a wholly admirable and unusual stirring of interest among lawyers, with some very definite results. But all too often this has resulted in what seem, in all frankness, to have been weak and uncourageous attacks on the old citadels by the leaders of reform. They have shown themselves too willing to accept the principle that "our own system is really very good, better than most, and needs only to be brought up to date here and there." Such an attitude is a compromise and a loss of the battle almost at the beginning. ${ }^{87}$

\section{VI}

\section{The Federal Reform in the States}

Immediately on the adoption of the rules there was a strong impetus for their consideration in the various states. Since agitation for procedural reform has been

ss The literature in favor of the rule-making authority in the courts is now so extensive that even the bibliographies cannot be included here. See Clark, Code Pleadivg 60-62 (2d ed. 1947); Harris, The Rule-Making Power (A. B. A. Jud. Adm. Monographs, Ser. A, No. 1), 2 F. R. D. 67 (1943); Fiftri Rep. N. Y. Jud. Council 271-312 (1939); Tenth Rep. N. Y. Jud. Council 159-I72 (1944); Rev. Rep. on Rule Making Power of the Supreme Court by the Judicial Council of the State of Minnesota (June 1 , 1944); and Memorandum, supra note 39 .

see note 53 , supra.

See note 38, supra, also notes 59, 60, 6I, infra.

see notes $1,2,39$, supra. 
widespread in recent years and since, among other protagonists, the American Bar Association was supporting the movement through general and state committees, ${ }^{5 s}$ it was but natural that the enthusiasm engendered by the new federal rules should produce results. Hence three states-Arizona, Colorado, and New Mexico-at once adopted the federal rules in full, with only very limited, and quite minor, changes needed for the adaptation. To date this is still the greatest achievement of the federal reform so far as the states are concerned. Almost as extensive a system was adopted under the favorable auspices of the state supreme court in Nebraska, only to achieve the unusual fate of opposition from the legal profession and complete repeal by the legislature. A like movement in Florida has been stopped, at least temporarily, notwithstanding the continuing activity of the state bar, by opposition within the highest court itself, expressed in favor of a hybrid system containing so many of the federal rules as to cast doubt upon the arguments urged against their full adoption. In Iowa, Missouri, and Texas the reform movements led to completely new codes or sets of rules. But here, unfortunately, local views prevailed, so that in each case the result is the same unfortunate hybrid system to which reference has just been made. ${ }^{59}$

More limited adaptations of parts of the federal system have occurred in Pennsylvania and in South Dakota, while comparatively smaller parts have been adopted in Maryland (dealing with discovery), New York (parties and their joinder), and other states. Many states have adopted provisions for pre-trial conferences modeled on the federal rules. Here, too, the results are varying. Thus the limited Pennsylvania reform seems not to have given satisfaction, and the rule-making committee has now been reconstituted with broader authority. Some of the South Dakota changes are symptomatic of some of the partial changes made twenty-five years ago in New York, which, by their conflicting inadequacies, caused unnecessary litigation there. ${ }^{60}$ Of course it is possible for certain special federal rules to be adopted

${ }^{B B}$ Particularly through its Special Committee on Improving the Administration of Justice under the leadership of Judge John J. Parker and the co-operating local state committees. The monographs sponsored by the Committee have been cited above; the bulletins give the latest reports from the field. Sec Bull. No. 10 (Aug. 1, 1947), cited notes $59,60,63$, infra.

"For citations sce Clark, Code Plending 50-54 (2d ed. 1947). For the Nebraska experience see the writer's article in 21 NEB. L. Rev. 307 (1942), also 21 id. 76, 94 (r942); 26 J. AM. Jub. Soc'r 170 (1943); Neb. Sess. Laws 1943, c. 63 (the repealing statute); 27 J. Ax. Jov. Soc'y 19 (1943). In Florida the court first held it lacked rule-making authority. In re Petition of Florida State Bar Ass'n, I45 Fla. 223, I99 So. 57 (I941). Then after the legislature had granted the authority, it refused adoption of the federal rules for an intermediate system, set forth by Mr. Justice Terrell, id. 155 Fla. 710, 21 So. 2d 605 (1945), I9 FLA. L. J. II9 (1945); and see also Justice Terrell's statements and articles in 20 FLA. L. J. 28, $28 \mathrm{r}$ (1946), and 21 FLA. L. J. 89 (1947). The bar appears to be still pressing for the full reform, 21 FLA. L. J. 60 (1947); 30 J. AM. JUd. Soc'Y 65 (1946), 29 id. 3r (1945); Bull. No. 10, cited note 58, supra. Articles critical of the limited reforms in Iowa, Missouri, and Texas, including the writer's article on the Texas rules in 20 Tex. L. Rev. 4 (194r), are cited in Clark, Code Plending 51, n. 145 (2d ed. 1947).

${ }^{\circ}$ For the limited changes in Maryland, Pennsylvania, and South Dakota and the criticisms thereof, particularly the local criticisms in Pennsylvania, see Cisrk, Code Plending 51, n. 146 (2d ed. 1947), and compare articles cited note 38 , supra; see also Bull. No. 10, cited note 58 , supra, for more recent activity in the latter state. For the New York revision of 1947 as to parties, see EleveNrH ReP. OF N. Y. Jud. Council 341-410, (1945) Twelfmi Rep. 163-232 (1946); and Clark, Code Pleading, c. 6 (2d ed. (1947). For pre-trial in the states, see authorities cited note 49 , supra, particularly 4 F. R. D. 83 . 
in default of further changes. Thus the pre-trial rule may be added to an already defined system. In general, however, I believe the principle sound that a hybrid reform is of doubtful value, perhaps even more doubtful than any change of system. Such a cross-sterilization causes all the uncertainty and confusion of the complete reform without the lasting benefits of the latter. Meanwhile it renders lasting change more difficult. ${ }^{61}$

There are other states where the federal reform has had less effect. Thus in Alabama reform was made extensively following the principles of English chancery, rather than the federal model. In New Jersey an attempt to unite law and equity, embodied in the new constitution, failed with the failure of that constitution. The activities of the new constitutional convention seem to be devoted to a somewhat more limited reform, achieving only separate law and equity "sides" of a single court, rather than the completely divided system of the past. ${ }^{62}$ There are active reform movements or pressures from the bar associations in numerous other states, including Delaware and Rhode Island. ${ }^{03}$ How long this ferment will last and how far it will go cannot now be prophesied. Even if the direct impetus from the federal achievement tends to lose momentum, the indirect consequences from the stimulus to wise thinking about procedural reforms which extended to the law schools and law reviews, and is now found in so many articles and books, together with the efforts of the American Bar Association and local associations to extend the system, should continue and perhaps even broaden indefinitely. And with the passage of time, the stimulus from the just adopted federal rules of criminal procedure will undoubtedly operate also to carry that reform to the states.

\section{VII}

\section{Toward A Procedural Jurisprudence.}

Many authorities have commented upon the absence from our legal system of anything approximating the procedural jurisprudence which is so striking a feature

${ }^{61}$ Thus Justice Terrell, supra note 59 , in opposing local adoption of the federal rules, states as a conclusion from his correspondence with state chief justices that since the effective date of the rulcs, thirty states have considered reform of their procedure and twenty-eight have not followed the federal system. 21 FLA. L. J. 89 (1947). He does not include Colorado among states which have fully adopted that system. See also note 63 , infra.

02 Reports in the daily press indicate the strong opposition to even this measure of reform in New Jersey. For earlier attempts, and for the Alabama change, see note 43, supra; Clark, Code Pleadino 28-30 (2d ed. 1947); Sims, New Alabama Equity Rules, I Ata. Lawy. 13 (1940). Happily the new constitution for New Jersey, achieving a considerable measure of (if, perhaps, not complete) union, was adopted at the November, 1947, election; and the choice of Dean Arthur T. Vanderbilt as the new Chief Justice insures wise and vigorous exercise of the rule-making and administrative powers which now go with that office.

${ }^{63}$ All such movements are discussed in Bull. No. Io, cited note 58 , supra, current numbers of the Journal of the American Judicature Society (cf. States Move to Modernize Civil Procedure, 24 J. AM. Jup. Soc'y 189 (I94I)), the articles cited in notes 33, 6r, sifpra, and Clark, Code Pleadino 50-54 (2d ed. 1947). In the book review by Stayton of Scott and Simpson, Cases and Materials on Jubrctat Rexredies (2d ed. 1946), 25 TEx. L. Rev. 558, at 564-566 (1947), there is an appendical note by the Research Librarian of the University of Texas Law School attempting to give citations of all state rule-making changes since the adoption of the federal rules. This is a helpful authority; but care in its use is. necessary, because it includes all amendments of appellate court rules, whether or not they affect trial court procedure, and it excludes statutory reforms such as those of Iowa and Missouri. 
of the continental and civil systems of law. Indeed, in the past there has been strong support for the idea that such a jurisprudence is both impossible and undesirable because of the need to emphasize local and particular systems. Distinguished lawyers and judges urged that law'schools could not present general courses on these subjects and that only the study of particular codes was worth while. Such particularism in approach to procedure may be a partial explanation for the multitude of limited, conflicting, and undesirable procedural decisions in this country. ${ }^{\text {es }}$

Hence any statement of means and methods toward a new procedural system may well conclude with a plea for an American procedural jurisprudence or philosophy. Possibly, since so many American lawyers are conditioned against it, we should not use the word "jurisprudence." Certainly no Austinian, Hohfeldian, or other formal scheme of jurisprudence is intended. Rather we are looking more for an attitude or approach which should not be limited to one particular topic or subject in the field of adjective law, but which should permeate and shape it all. Some may say that this is to achieve the very emphasis upon the subject which it is the intent of modern procedure to avoid. ${ }^{65}$ But what is contemplated is certainly not a new apotheosis of procedure. Rather it is the view that a lack of appreciation and understanding, even of willingness to bother with the modern philosophy of pleading, is the cause of many of the surprising procedural results.

It may well be urged that the abler the court, the more likely are strange procedural decisions to be forthcoming. This is a view contrary to the oft-repeated dogma that our judiciary is too politically chosen, too lacking in deep experience, to understand and operate a flexible, discretionary system of procedure. But in truth, if these criticisms are at all true of the American judiciary, they afford the strongest reasons for such a system. If examples were not invidious, one could point to the marked success with such systems by many judges who do not aspire to be named as world-renowned legal philosophers and who might confess to political pasts. ${ }^{\text {"6 }}$ On the other hand, many of the great judges tend to look down upon pleading as unworthy of great thoughts, and hence stumble over some of the more trite problems which a deeper appreciation would have enabled them to avoid. Moreover, and most doubtfully, they resort to pleading rules often literally manufactured

"See discussion, with citations, in CLARK, CODE Pleading 69-71 (2d ed. r947). For a broader approach see Vanderbilt, Iudicial Administration in the Law School Curriculum, 27 J. AM. Jud. Soc'y 179 (1944); McDonald, The Procedure Curriculum in a Period of Reform, 9 AM. L. School REv. 1053 (1941); Maynard E. Pirsig, Cases and Materials on Judicial Administratton (i946).

of Thus Professor Stayton says in the book review cited note 63, supra, 25 Tex. L. Rev. 558, 563 (1947): "Then, too, procedure is tending to become unimportant and procedural statutes are more and more taking the form of rules." He then goes on to speak appreciatively of "the principle of adaptation to justice." But however desirable, the principle is not so simple as that of justice according to the length of the chancellor's foot.

${ }^{\circ 0}$ Would it be out of place to suggest that those judges who have come to the federal bench from the halls of Congress or other governmental office are among the finest expositors of the federal rules? Conversely one may ask how the outwardly precise, but actually vague, abstractions of a Field Code may help a new and innocent judge to know the facts of judicial life. 
for the occasion, although given a semblance of antique aura without basis in fact. As such decisions ripple down from the higher appellate courts to the lower trial courts they render procedure increasingly doubtful, confusing, and arbitrary ${ }^{07}$ It hardly befits the dignity of courts thus to conceal from litigants the real bases of their decisions. Perhaps momentarily it may seem easier or shorter for a court to rely on ancient assumed verities of procedure than upon a rehearsal of the equities in support of its actual decision. But in the long run this seems a stultifying process. Would it not be better, notwithstanding the possibility of criticisms of partiality by some defeated litigants, if the real basis of the decision were to be asserted and the procedural rules kept in their more appropriate subordinate position?

Therefore the greatest consequence of the new federal procedural system and its success in operation may well be a new orientation toward the whole subject of adjective law and the development of something more closely approaching a philosophy as to its place in the American legal scheme than it has had in the past. In short, the true impetus of the federal reform is toward a greater understanding of the subject. With understanding comes the power to use it appropriately and within its proper realm.

oz See Clark, Code Pleading 7x (2d ed. 1947). Thus teaching of the subject is foreed into the situation of collecting "horrible examples" of "waste motion in the legal process." Brandis, II FonD. L. Rev. 122 (1942), reviewing and referring to Clarx, Cases on Pleading and Procedure (2d ed. 1940). Supplemental note: Since this article was prepared I have learned that effective January 1,1948 , Dclaware has adopted the federal rules in its Superior Court (its trial court for law actions), including the amendments not effective in federal practice until March 19, 1948, and setaining the federal numbering notwithstanding the omission here and there of a federal provision. 